\title{
PELATIHAN MERANCANG ALAT PRAKTIKUM DAN PEMANTAPAN MATERI FISIKA SMP BAGI GURU-GURU FISIKA
}

\author{
Sixtus I. Umboh \\ Jurusan Fisika, Fakultas Matematika dan Ilmu Pengetahuan Alam, UNIMA \\ iwan_umboh@yahoo.co.id
}

\begin{abstract}
Kegiatan ini bertujuan untuk meningkatkan kreatifitas guru fisika dalam merancang pembelajaran baik di dalam kelas maupun di Laboratorium dan meningkatkan profesional guru fisika agar mampu membuat alat eksperimen. Mengadakan pelatihan dalam merancang alat praktikum sederhana yang dapat digunakan untuk menampakkan gejala fisis dan pemantapan materi berkaitan dengan alat yang dikembangkan bagi guru IPA Fisika. Kegiatan ini berpusat pada pelayanan masyarakat (dalam hal ini masyarakat pendidikan) dan bersifat komplementer dalam arti memperkuat atau menunjang kegiatan yang sudah ada. Metode yang digunakan adalah eksperimen, diskusi, Tanya jawab dan ceramah bervariasi. Tempat pelaksanaan kegiatan dipusatkan di SMP Negeri 3 Kawangkoan. Hasil kegiatan yaitu memberikan pelatihan dalam bentuk merancang alat sederhana yang dibuat dengan bahan baku yang ada dilingkungan sekitarnya dan memberikan ceramah sehubungan dengan pemantapan materi Fisika dengan menggunakan metode ceramah, diskusi, Tanya jawab. Hasil luarannya meliputi Modul Praktikum Fisika untuk SMP dan perangkat alat praktikum buatan guru.

Keywords: Alat praktikum, perancangan, materi Fisika.
\end{abstract}

\section{PENDAHULUAN}

Dalam meningkatkan mutu pendidikan di tanah air kita, pemerintah menempuh berbagai kebijakan anatara lain melalui jalur peningkatan mutu. Unima sebagai suatu Lembaga Pendidikan Tenaga Kependidikan mempunyai tanggung jawab yang sangat besar dalam upaya peningkatan mutu pendidikan, khususnya di Sulawesi Utara, karena UNIMA adalah lembaga penghasil tenaga guru. Peranan yang dapat dilakukan oleh Unima di Tondano dalam hal ini adalah di samping berusaha membentuk dan menghasilkan calon-calon guru yang benar-benar memiliki kemampuan profesional, FMIPA Unima berkewajiban pula untuk ikut serta secara langsung melalkukan usaha-usaha untuk membantu meningkatkan kualitas pembelajaran di sekolah-sekolah.
Fisika adalah salah satu cabang Ilmu pengetahuan Alam, menurut Herbert (1986:12) secara keseluruhan fisika dapat dianggap sebagai ilmu pengetahuan yang berusaha menguraikan, menjelaskan hukum-hukum dan kejadian-kejadian alam dengan gambaran menurut pemikiran manusia, sejalan itu menurut Brockhous (1972) IPA adalah suatu kumpulan pengetahuan yang tersusun yang diperoleh dengan menggunakan metode-metode berdasarkan observasi (Tim Fisika, 1994 : 8). Fisika adalah bagian dari IPA, selanjutnya Carin menyatakan bahwa IPA adalah "kumpulan pengetahuan yang tersusun secara sistematis". Dalam penggunaannya secara umum terbatas pada gejala-gejala alam (Amin 1987 : 10). Sedangkan Wigner seorang ahli fisika menyatakan bahwa "science atau Ilmu 
Pengetahuan alam sebagai kumpulan pengetahuan tentang alam" (Poedjiadi, $1987: 10)$.

Hakikat Fisika sama dengan hakikat sains karena fisika merupakan bagian yang tak terpisahkan dari sains. Fisika merupakan salah satu cabang dari sains, dan merupakan ilmu yang lahir dan berkembang lewat langkah-langkah observasi, perumusan masalah, penyusunan hipotesis, pengujian hipotesis melalui eksperimen, penarikan kesimpulan, serta penemuan teori dan konsep. Dan dapat dikatakan bahwa hakikat fisika adalah ilmu pengetahuan yang mempelajari gejalagejala melalui serangkaian proses yang dikenal dengan proses ilmiah yang dibangun atas dasar sikap ilmiah yang hasilnya terwujud sebagai produk ilmiah yang tersusun atas tiga komponen terpenting berupa konsep, prinsip, dan teori yang berlaku secara universal.

Fisika adalah bangun pengetahuan yang menggambarkan usaha, temuan, wawasan, dan kearifan yang bersifat kolektif dari umat manusia. Ditinjau dari aspek tujuan atau kemampuan dasar yang ingin dicapai, mata pelajaran fisika menekankan pada penguasaan konsep dan saling keterkaitannya untuk diterapkan pada pemecahan masalah. Karakteristik pengajaran fisika merupakan aktifitas manusia yang bertujuan menemukan keteraturan alam melalui pengamatan, pengukuran, eksperimen, pengujian dan penarikan suatu kesimpulan. Mata pelajaran 78 fisika di SMA dikembangkan dengan mengacu pada pengembangan dan karakteristik fisika yang ditujukan untuk mendidik siswa agar mampu mengembangkan observasi dan eksperimentasi serta bersifat taat azas. Kemampuan observasi dan eksperimentasi lebih ditekankan pada melatih kemampuan berfikir eksperimental yang mencakup tata laksana percobaan dengan mengenal peralatan yang digunakan dalam pengukuran baik di dalam laboratorium maupun di alam disekitar kehidupan kehidupan siswa, yakni mulai dari kajian sederhana diteruskan yang lebih kompleks.

Tujuan pengajaran fisika adalah agar siswa memahami konsep-konsep fisika. (SMP dan SMA) tidak dilaksanakn. Kebetulan pada beberapa tahun terakhir ini UNIMA menerjunkan mahasiswa PPL di Kabupaten Minahasa Induk diperkirakan hanya sekitar 25\% sekolah yang melaksanakan kegiatan praktikum IPA- Fisika walaupun ketersediaan laboratorium ada tetapi terkesan tidak terurus. Pada hal karakter pembelajaran Fisika selalu berhubungan dengan pengukuran, belajar tentang gejala alam, berate belajar sambil eksperimen sehingga memerlukan guru yang kreatif dan mampu mengelola/ membuat alat peraga dengan memanfaatkan fasilitas yang ada dilingkungan sekitar.

Demikian juga ditemukan di sekolah-sekolah yang mengajar IPA-Fisika bukan berasal dari jurusan Fisika oleh sebab itu perlu diadakan kegiatan pelatihan dan pemantapan materi IPA - Fisika badi 
guru-guru Fisika. Peralatan (Kit) yang tersedia sangat minim tidak sesuai dengan pokok-pokok bahasan yang diajarkan padahal bisa menggunakan alat peraga dengan mengelolah apa yang ada dilingkungan sekitar.

Kenyataan-kenyataan itu memberikan petunjuk bahwa mutu pendidikan/ pengajaran Fisika di sekolah-sekolah di Sulawesi Utara masih rendah. Guru yang kreatif benar-benar dibutuhkan saat ini dalam rangkah membangkitkan motivasi dan gairah belajar peserta didik melalui pemanfaatan alat praktikum. Pada kesempatan ini sebagai tanggung jawab terhadap keberhasilan kegiatan pembelajaran kami mengadakan kegiatan pelatihan praktikum dan pemantapan materi Fisika di SMP kecamatan Kawangkoan bagi guru-guru Fisika. Hal ini dilakukan dalam rangka meningkatkan kualitas pembelajaran Fisika SMP melalui kegiatan pengabdian pada masyarakat. Sesungguhnya apa yang kita lakukan merupakan wujud tanggung jawab kita menghasilkan individu yang kreatif dan mandiri yang saat ini sudah menjadi kebutuhan masyarakat, sebagai salah satu kegiatan dalam mewujudkan Tridarma Pendidikan Tinggi khususnya dalam bidang pengabdian pada masyarakat.

\section{METODE PENGABDIAN}

\footnotetext{
Waktu pelaksanaan kegiatan adalah dua minggu meliputi persiapan dan pelaksanaan, dimana pelaksanaan secara padat berlangsung dari tanggal 8 Nopember
}

2015 s/d 22 Nopember 2015; kegiatan setiap hari memakan waktu 5 sampai 7 jam efektif. Tempat pelaksanaan kegiatan dipusatkan di SMP Negeri 3 Kawangkoan. Peserta adalah guru-guru IPA Fisika. Jumlah peserta yang diundang 25 orang dan yang telah mengikuti 18 orang dan yang efektif 15 orang

\section{HASIL DAN PEMBAHASAN}

Memberikan pelatihan dalam bentuk merancang alat sederhana yang dibuat dengan bahan baku yang ada dilingkungan sekitar seperti kayu papan. Alat-alat yang digunakan untuk membuat alat percobaan yaitu engsel pintu, baut, mistar, busur dan meteran baju. Selanjutnya memberikan ceramah, diskusi, dan Tanya jawab. Ceramah diberikan dengan menjelaskan tentang teori dan konsep Fisika. Setelah selesai ceramah dilanjutkan dengan diskusi. Kegiatan diskusi melibatkan peserta dari guru masing-masing sekolah yang sudah dibentuk kelompok. Masingmasing kelompok diskusi memberikan tanggapan dan saran kepada kelompok diskusi lainnya. Hasil diskusi kelompok menunjukan adanya beberapa peserta dalam kelompok diskusi memahami materi yang disampaikan oleh peserta maupun moderator. Sedangkan untuk kegiatan Tanya jawab oleh peserta pelatihan yang terdiri dari guru masing-masing sekolah menunjukkan adanya respon positif. Sehingga proses jalannya kegiatan ini berlangsung dengan baik. Pelaksanaan 
kegiatan pelatihan pembuatan alat praktikum dilaksanakan di ruang laboratorium, dengan peserta guru dari masing-masing sekolah mengambil alat-alat dan bahan baku yang sudah tersedia. Pekerjaan dalam merancang alat dipandu oleh instruktur / Dosen Fisika dari Unima. Hasil kegiatan ini diperoleh Modul Praktikum Fisika untuk SMP dan Perangkat alat Praktikum Fisika buatan guru.
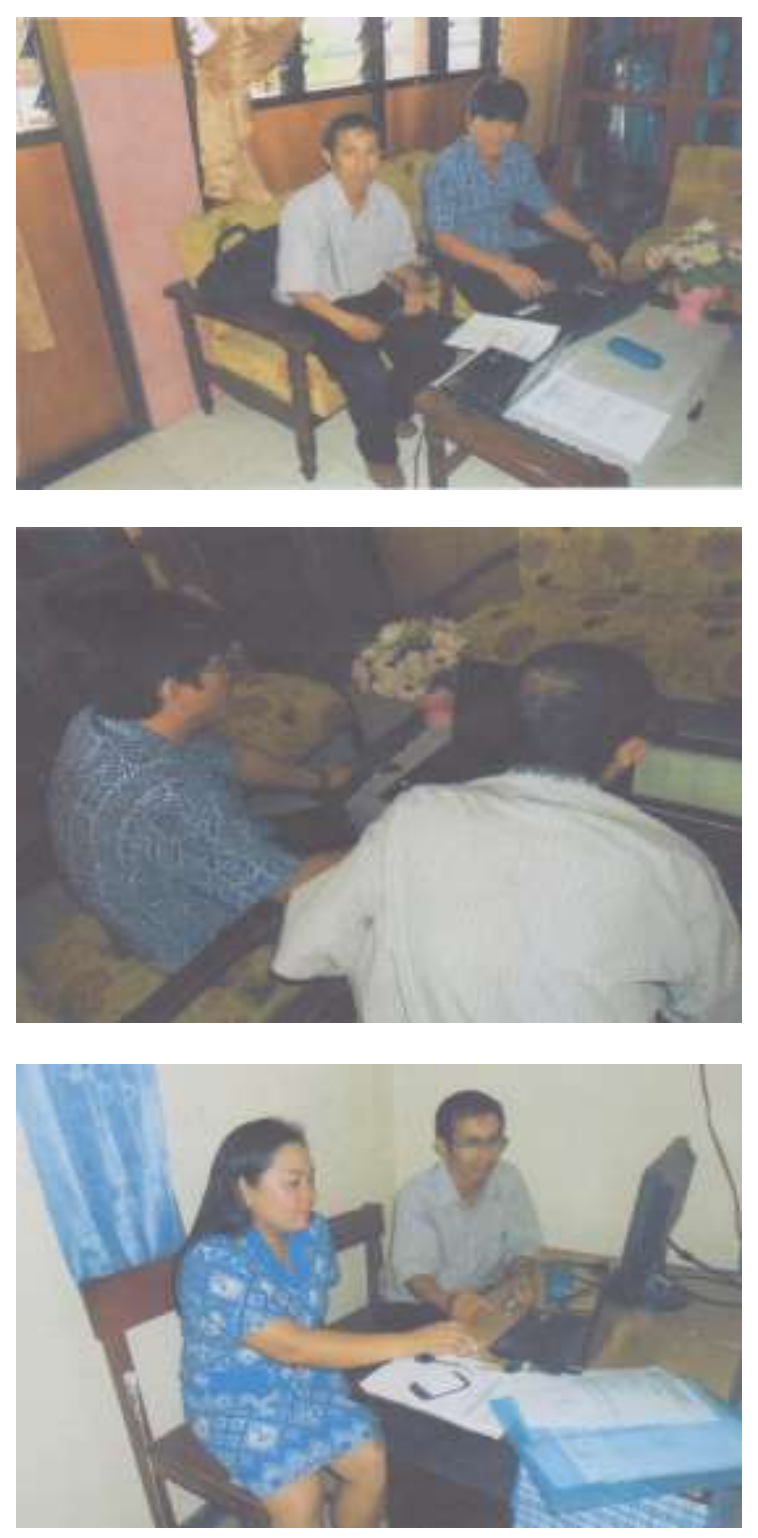

Gambar 1. Dokumentasi Kegiatan.

\section{KESIMPULAN DAN SARAN}

\section{Kesimpulan}

1. Dengan adanya pelatihan ini kekurangan alat praktikum dapat diatasi dan fasilitas Laboratorium, tidak hanya bergantung buatan pabrik tetapi bisa menggunakan alat peraga Buatan guru;

2. Pemantapan materi bagi guru-guru IPA Fisika sekolah lanjutan sangat bermanfaat dalam pengembangan wawasan pembelajaran Fisika menjadi seorang guru professional; dan

3. Pengabdian ini membangkitkan produktifitas badi guru-guru dalam merancang alat peraga sehingga membuat kegiatan pembelajaran menarik.

\section{Saran}

1. Kegiatan pelatihan ini dapat ditindak lanjuti secra berkelanjutan pada tingkat SMA.

2. Pemantapan materi Fisika perlu dilakukan mengingat guru Fisika di SMP bukan saja berasal dari lulusan Fisika tetapi ada juga dari bidang lain.

3. Dengan adanya pelatihan ini kekurangan alat praktikum dapat diatasi dan fasilitas laboratorium, tidak hanya bergantung buatan pabriktetapi bisa menggunakan alat peraga buatan guru.

\section{KEPUSTAKAAN}

Arthur A. Carin. 1997. Teaching Modern Science. Colombus : Printice Hal. 
Herbert Druxes. 1996. Kompedium Didaktik Fisika. Remaja Rodaskarya.

Koes, S.H. 2003. Strategi Pembelajaran Fisika. Jurusan Fisika FMIPA Universitas Negeri Malang : JICA.

Mikrajuddin Abdullah, 2007. FISIKA 2A. Bandung : Erlangga.

Nasution. 1982. Berbagai Pendekatan dalam Proses Belajar dan Mengajar. Bandung : Bumi Aksara.
Supiyanto. 2006. Fisika SMA Kelas XI. Jakarta : Erlangga.

Trianto. 2008. Mendesain Pembelajaran Kontekstual ( Contextual Teaching and Learning) Di Kelas. Jakarta : Cerdas Pustaka Publisher.

Trianto. 2007. Model-model Pembelajaran Inovatif Berorientasi. Jakarta Prestasi Pustaka Publisher. 
Jurnal ABDIMAS, Vol. 10, No. 01, Juni 2017 ISSN: 1979-0953 